\title{
Dopamine DI Receptors in Cocaine Dependence Measured with PET and the Choice to Self-Administer Cocaine
}

\author{
Diana Martinez*,', Mark Slifstein', Rajesh Narendran', Richard W Foltin', Allegra Broft', Dah-Ren Hwang', \\ Audrey Perez', Anissa Abi-Dargham', Marian W Fischman', Herbert D Kleber' and Marc Laruelle ${ }^{1,2}$ \\ 'Department of Psychiatry, Columbia University College of Physicians and Surgeons, New York, NY, USA; ${ }^{2}$ Department of Radiology, Columbia \\ University College of Physicians and Surgeons, New York, NY, USA
}

\begin{abstract}
The goal of this study was to determine $D_{1}$ receptor availability in human cocaine-dependent (CD) subjects and matched healthy controls (HCs). In addition, the CD subjects performed cocaine self-administration sessions in order to explore the association between

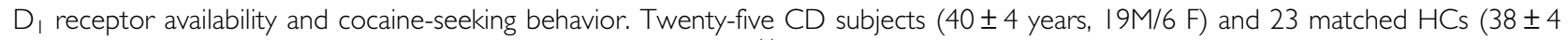
years, 19M/4F) were scanned with PET and the radiotracer $\left[{ }^{1} \mathrm{C}\right] N N C$ II2. During the cocaine self-administration sessions, CD volunteers were given the choice to self-administer cocaine $(0,6$, and $12 \mathrm{mg})$ or to receive a monetary voucher worth $\$ 5$. $D$, receptor availability was measured in the limbic, associative, and sensori-motor striatum in addition to cortical brain regions. No difference in $D$, receptor availability was seen between the two groups. A negative association was seen between $D_{1}$ receptor $B P_{N D}$ in the limbic striatum and the choice for the $6 \mathrm{mg}$ dose of cocaine $(r=-0.47, p=0.02$, corrected for age). These results do not support the hypothesis that cocaine dependence is associated with a reduction in $D_{1}$ receptor availability in the striatum. However, within the $C D$ subjects, low D, receptor availability in the ventral striatum was associated with the choice to self-administer cocaine, suggesting that low $D_{1}$ receptor availability may be associated with an increased risk of relapse in cocaine dependence.

Neuropsychopharmacology (2009) 34, 1774- 1782; doi:I 0.1038/npp.2008.235; published online 28 January 2009
\end{abstract}

Keywords: PET; D, receptor; cocaine; cocaine-seeking behavior; striatum; limbic striatum

\section{INTRODUCTION}

Recent studies investigating the role of the $\mathrm{D}_{1}$ receptor in animal models of cocaine dependence suggest that increased signaling, at this receptor, may provide a novel treatment approach for this disorder (Self et al, 1996a, 2000). In animal models of cocaine dependence, the administration of a $\mathrm{D}_{1}$ agonist attenuates cocaine-seeking behavior elicited by a priming dose of cocaine in rodents and non-human primates (De Vries et al, 1999; Dias et al, 2004; Khroyan et al, 2000; Self et al, 1996a). Similar results have shown that a $D_{1}$ agonist also reduces cue-induced cocaine-seeking behavior (Alleweireldt et al, 2002). In a related study, rats with higher preferred levels of cocaine self-administration were found to be less sensitive to $D_{1}$ mediated inhibition of cocaine-seeking behavior, compared with rats having lower levels of cocaine intake (Edwards et al, 2007). Alternatively, $\mathrm{D}_{1}$ antagonists administered

*Correspondence: Dr D Martinez, New York State Psychiatric Institute, I05I Riverside Drive, Box \#31, New York, NY I0032, USA, Tel: +212543 6628, Fax: + 2125686171 ,

E-mail: dm437@Columbia.edu

Received 13 August 2008; revised 10 November 2008; accepted 2 December 2008 directly into the nucleus accumbens have been shown to increase cocaine self-administration in rodents (Caine $e t$ al, 1995; Maldonado et al, 1993). Taken together, these data suggest that excessive cocaine self-administration may be associated with a loss of signaling at the $\mathrm{D}_{1}$ receptor, and that $D_{1}$ receptor blockade in the nucleus accumbens may increase the risk of relapse.

In line with this theory, it might be expected that cocaine dependence is associated with a decrease in $D_{1}$ receptor availability. However, earlier studies in rodents and nonhuman primates have shown both a decrease (Farfel et al, 1992; Kleven et al, 1990; Moore et al, 1998), as well as an increase (Lim et al, 1990; Nader et al, 2002; Unterwald et al, 1994 ) in striatal $D_{1}$ receptors after chronic exposure to cocaine. In humans, a post-mortem study showed that striatal $\mathrm{D}_{1}$ receptor mRNA was unchanged in chronic cocaine abusers, although $D_{1}$ receptor density was not measured (Meador-Woodruff et al, 1993). Only one earlier study has used PET imaging to measure changes in $D_{1}$ receptor binding associated with cocaine exposure, and this study showed a significant decrease in rodents exposed to cocaine for at least 7 days (Tsukada et al, 1996).

In order to investigate the effects of cocaine dependence on $\mathrm{D}_{1}$ receptor availability, we used PET and the radiotracer $\left[{ }^{11} \mathrm{C}\right] \mathrm{NNC} 112$ in a group of human cocaine-dependent (CD) 
subjects and matched healthy controls (HCs). Following the PET scans, the $C D$ subjects underwent cocaine selfadministration sessions in order to explore the association between $D_{1}$ receptor availability and cocaine-seeking behavior. Animal studies have shown that a priming dose of cocaine reinstates cocaine self-administration (Khroyan et al, 2000; Self et al, 1996a; Shaham et al, 2003), and a similar laboratory model has been developed for human subjects (Foltin et al, 2003; Martinez et al, 2004). In this model, non-treatment seeking, recently detoxified CD volunteers were given the choice to self-administer cocaine over an alternative reinforcer (money) after a responseindependent ('priming') dose of cocaine. The self-administration sessions provide a measure of each subject's vulnerability to the reinforcing effects of cocaine, which can then be correlated with $D_{1}$ receptor availability. Our hypotheses were: (1) cocaine dependence would be associated with a decrease in $D_{1}$ receptor availability in the ventral striatum (VST), and (2) the CD subjects with the lowest $\mathrm{D}_{1}$ receptor availability in the VST would be more likely to choose cocaine over an alternative reinforcer, in the self-administration sessions.

\section{MATERIALS AND METHODS}

\section{Human Subjects}

The study was approved by the Institutional Review Board of the New York State Psychiatric Institute. All subjects provided written informed consent. The $\mathrm{CD}$ volunteers were medically healthy, and fulfilled the DSM-IV criteria for cocaine dependence, with no other current axis I diagnosis. The CD participants had weekly cocaine use greater than the amount of cocaine used in this study, and tested positive for cocaine (urine toxicology) at screening. They were not seeking treatment, but were informed that a referral for treatment was available. CD subjects were required to use alcohol or cannabis less than twice a week and no use of prescription medications or other illicit drugs was permitted in the 6 months prior to study entry. Seventeen of the $\mathrm{CD}$ subjects had been scanned with another radiotracer in an earlier reported study (Martinez et al, 2004). HC subjects were between the ages of 21 and 45 and had no current or past DSM-IV Axis I disorder. Nicotine dependence was acceptable for both groups.

The CD subjects were admitted to the Irving Center for Clinical Research at the New York Presbyterian Hospital and underwent random urine tests to confirm abstinence. The PET scans were performed after 14 days of abstinence, and the cocaine self-administration sessions were performed 2-3 days after the PET scans.

\section{PET Scan Acquisition}

$\left[{ }^{11} \mathrm{C}\right] \mathrm{NNC} 112$ was synthesized as described previously (Halldin et al, 1998), and injected intravenously over $45 \mathrm{~s}$ after a transmission scan. Emission data were acquired using the ECAT EXACT HR + camera in 3D mode for $90 \mathrm{~min}$, as described previously (Abi-Dargham et al, 2000). The arterial input was obtained by collecting arterial samples every $10 \mathrm{~s}$ with an automated sampling system (for the first $2 \mathrm{~min}$ ) followed by manual samples at longer intervals, for a total of 30 samples. Six samples were collected (at 2, 8, 16, 30, 50, and $70 \mathrm{~min}$ ) and further processed by high-pressure liquid chromatography to measure the percent of plasma activity representing unmetabolized (parent) $\left[{ }^{11} \mathrm{C}\right] \mathrm{NNC} 112$. The measured input function values $\left(\mathrm{C}_{\mathrm{a}}(\mathrm{t}), \mu \mathrm{Ci} / \mathrm{ml}\right)$ were analyzed as described previously and used for the kinetic analysis of the regional brain uptake (Abi-Dargham et al, 2000). The clearance of the parent compound $\left(C_{\mathrm{L}}, 1 / \mathrm{h}\right)$ was calculated as the ratio of the injected dose to the area under the curve of the input function. The plasma-free fraction $\left(\mathrm{f}_{\mathrm{P}}\right)$, was calculated as the ratio of the ultrafiltrate to the total activity concentration as described previously (Abi-Dargham et al, 2000).

\section{PET Image Analysis}

Image analysis was performed in MEDx (Sensor Systems, Inc., Sterling, VA) using a region of interest (ROI) analysis as described previously (Abi-Dargham et al, 2000). Correction for head movement and co-registration of the PET data to the MR were performed using the automated image registration (Woods et al, 1992, 1993). The ROIs were identified on each individual subject's MRI, acquired on the GE 1.5 T Signa Advantage system. The ROIs included both cortical and subcortical regions. The subcortical regions included the striatum (STR), amygdala, and hippocampus. The STR was divided into the caudate, putamen, and VST. The caudate and putamen were further subdivided along their rostral-caudal axis using the anterior commissure to derive the following ROIs: (1) preDCA (pre-commissural dorsal caudate), (2) preDPU (pre-commissural dorsal putamen), (3) the postCA (post-commissural caudate), and (4) the postPU (post-commissural putamen). The striatal ROIs were classified as belonging to the limbic striatum (LST), associative striatum, or sensori-motor striatum, based on cortical connectivity (for reviews, see Haber and Fudge, 1997; Joel and Weiner, 2000). The LST corresponded to the VST, the associative striatum activity was derived as the spatially weighted average of the activities in the preDCA, preDPU, and postCA, and the sensori-motor striatum corresponded to the postPU. Details of the anatomical criteria and functional classification of the STR have been described previously (Martinez et al, 2003). The cortical regions included the dorsolateral prefrontal cortex, medial prefrontal cortex, orbitofrontal cortex, parietal cortex, temporal cortex, occipital cortex, and anterior cingulate cortex as described previously (AbiDargham et al, 2000). A segmentation procedure was implemented for the cortical regions so that only the voxels classified as gray matter were used to measure the activity distribution (Abi-Dargham et al, 2000). For all bilateral regions, right and left values were averaged.

\section{PET Outcome Measures}

The regional distribution volumes $\left(\mathrm{V}_{\mathrm{T}}\right.$, milliliter of plasma per gram of tissue) were derived with a kinetic analysis using the arterial input function as described previously (Abi-Dargham et al, 2000). A one-tissue compartment was used in the cerebellum (CER), and a two-tissue compartment in other regions. $\mathrm{D}_{1}$ receptor availability was calculated with two outcome measures: $\left[{ }^{11} \mathrm{C}\right] \mathrm{NNC} 112$ 
binding potential $\left(\mathrm{BP}_{\mathrm{P}}, \mathrm{ml} / \mathrm{g}\right)$ and the specific to nonspecific partition coefficient ( $\mathrm{BP}_{\mathrm{ND}}$, unitless) (Innis et al, 2007; Slifstein and Laruelle, 2001).

$\mathrm{BP}_{\mathrm{P}}$ and $\mathrm{BP}_{\mathrm{ND}}$ are defined as:

$$
\begin{aligned}
& B P_{\mathrm{p}}=V_{\mathrm{T} \mathrm{ROI}}-V_{\mathrm{T} \text { CER }}=f_{\mathrm{p}} * \frac{B_{\mathrm{MAX}}}{K_{D^{\prime}}} \\
& B P_{\mathrm{ND}}=\frac{V_{T R O I-} V_{\mathrm{T} \mathrm{CER}}}{V_{\mathrm{T} \text { CER }}}=f_{\mathrm{ND}} * \frac{B_{\mathrm{MAX}}}{K_{\mathrm{D}^{\prime}}}
\end{aligned}
$$

$\mathrm{V}_{\mathrm{T}}\left(\mathrm{ml} \mathrm{g}^{-1}\right)$ is the regional tissue distribution volume for the ROIs and CER, fND is the free fraction in the nonspecific distribution volume of the brain, $f_{P}$ is the free fraction in the plasma, $B \max$ is the concentration of $D_{1}$ receptors (nmol/g of tissue), and $K_{\mathrm{D}^{\prime}}$ is the in vivo equilibrium dissociation constant of the radiotracer in the presence of dopamine (Slifstein and Laruelle, 2001). $\mathrm{V}_{\mathrm{T}} \mathrm{CER}$ was measured for each subject in order to ensure that there was no difference in non-specific binding between the two groups. The contribution of total plasma activity to the regional time activity data was calculated assuming a fixed $5 \%$ blood volume in the ROIs(Mintun et al, 1984). It should be noted that $\left[{ }^{11} C\right] N N C 112$ labels both the $D_{1}$ and $D_{5}$ receptors, and the term $D_{1}$ is used to denote both receptors.

\section{Self-Administration Sessions}

The CD subjects underwent two types of cocaine selfadministration sessions: sample sessions and choice sessions. In the sample sessions, the subjects self-administered a single dose of smoked cocaine $(0,6$, or $12 \mathrm{mg}$ of cocaine, one session of each dose per subject). The subjects were asked to rate the subjective effects at baseline, and at 4, 14, 30 , and $60 \mathrm{~min}$ after the dose. The computerized subjective effects battery consisted of visual analog scales labeled 'not at all' at $0 \mathrm{~mm}$ and 'extremely' at $100 \mathrm{~mm}$, as described previously (Foltin et al, 1990). A previous cluster analysis showed that the visual analog scale 'good drug effect', 'high', and 'stimulated' can be grouped into the positive effects cluster (Evans et al, 2002). The positive effects cluster was chosen $a$ priori for correlation with $\mathrm{D}_{1}$ receptor availability. For each visual analog scale, the area under the curve was calculated relative to the baseline score and the positive effects score was derived as the average area under the curve for the visual analog scale within this cluster.

In the choice sessions, the $\mathrm{CD}$ subjects underwent three cocaine self-administration sessions with 0,6 , and $12 \mathrm{mg}$ doses of smoked cocaine presented in counterbalanced order, as described previously (Foltin et al, 2003; Martinez et al, 2004). Each session began with a response-independent or 'priming' dose of cocaine $(0,6$, or $12 \mathrm{mg})$. After this dose, subjects were given the choice between the same dose of cocaine or a $\$ 5$ merchandize voucher redeemable at local stores and paid upon discharge. The subjects were presented with this choice five times, spaced 14 min apart. Participants were required to press a space bar in order to receive their choice using a progressive ratio $(200,600$, 1000,1400 , and 1600 responses required). The outcome measure for the choice sessions was the number of times a given dose of cocaine was chosen over voucher (range $0-5$ ).

\section{Statistical Analysis}

Group demographic comparisons were performed with unpaired $t$-tests. Differences in $\left[{ }^{11} \mathrm{C}\right] \mathrm{NNC} 112 \mathrm{BP}_{\mathrm{P}}$ and $\mathrm{BP} \mathrm{ND}_{\mathrm{N}}$ between the $\mathrm{CD}$ and $\mathrm{HC}$ were analyzed by multivariate analysis of variance. The vector of regional $\mathrm{BP}_{\mathrm{P}}$ and $\mathrm{BP}_{\mathrm{ND}}$ measurements was the multivariate statistic. Post hoc tests, when indicated, were performed by region, controlling the false discovery rate at the $\alpha=0.05$ level. Regional volumes were also compared across groups by multivariate analysis of variance. Unpaired $t$-tests were used to compare differences in scan parameters, $V_{\text {TCER }}$ and $f_{1}$ between the two groups.

The correlation of $\mathrm{D}_{1}$ receptor availability and cocaineseeking behavior was analyzed by linear regression between $\mathrm{BP}_{\mathrm{P}}$ and $\mathrm{BP}_{\mathrm{ND}}$ and the choice for cocaine. For this analysis, the VST was chosen a priori for correlation with the choice for a $6 \mathrm{mg}$ dose of cocaine. Exploratory analysis was performed to examine the correlation between receptor availability and the positive effects of cocaine. A two-tailed probability value of $p<0.05$ was chosen as the level of significance for these analyses.

\section{RESULTS}

\section{Group Comparison}

Twenty-five CD subjects and $23 \mathrm{HC}$ subjects were enrolled in this study. The group demographics are shown in Table 1. Here, of the $25 \mathrm{CD}$ subjects, one completed the PET scans and the self-administration sample session, but not the choice session because of a scheduling conflict. The CD subjects had been smoking crack cocaine for an average of $16.4 \pm 4.5$ years and had spent an average of $\$ 264 \pm \$ 118$ / week over the last 6 months.

\begin{tabular}{|c|c|c|c|}
\hline Parameter & $\mathrm{HC}$ & CD & $\mathbf{p}$ \\
\hline$n$ & 23 & 25 & - \\
\hline Age (mean $\pm S D$, years) & $38 \pm 4$ & $40 \pm 4$ & 0.33 \\
\hline Gender (Male/Female) & $19 \mathrm{M} / 6 \mathrm{~F}$ & $19 \mathrm{M} / 4 \mathrm{~F}$ & - \\
\hline Ethnicity (Afro-American/Hispanic/Caucasian not Hispanic) & $16 \mathrm{AA} / 4 \mathrm{H} / 5 \mathrm{C}$ & I2AA/5H/6C & 0.61 \\
\hline Smoking status (Yes/Ex/No) & 16Y/3E/4N & 19Y/3E/3N & 0.53 \\
\hline
\end{tabular}

Table I Group demographics

$\mathrm{CD}$, cocaine dependent; $\mathrm{HC}$, healthy control. 


\section{PET Scan Parameters}

There was no significant difference between the two groups with respect to injected dose (HC: $14.3 \pm 3.4 \mathrm{mCi}, \mathrm{CD}$ : $13.1 \pm 4.2 \mathrm{mCi} ; \quad p=0.38$ ) or specific activity (HC: $1007 \pm 456 \mathrm{Ci} / \mathrm{mmol}, \mathrm{CD}: 969 \pm 454 \mathrm{Ci} / \mathrm{mmol} ; p=0.77)$. Plasma clearance did not differ between groups (HC: $83.6 \pm 31.21 / \mathrm{h}, \mathrm{CD}: 93.0 \pm 27.41 / \mathrm{h} ; p=0.28)$ nor did the plasma free fraction $\left(f_{1}\right) \quad(H C: 0.88 \pm 0.41 \%$, CD: $0.86 \pm 0.36 \% ; p=0.89)$. The volume of distribution of the cerebellum ( $\mathrm{V}_{\text {TCER }}$ ) was $2.17 \pm 0.49 \mathrm{ml} / \mathrm{g}$ in $\mathrm{HC}$ subjects and $2.32 \pm 0.46 \mathrm{ml} /$ gin $\mathrm{CD}$ subjects $(p=0.28)$.

The volumes of the ROI for each group were analyzed with a multivariate analysis of variance, which did not show a significant volume difference between groups (Hotelling's trace, $p=0.102$ ). Two regions did have low $p$ values when unpaired $t$-tests were applied on individual regions (orbitofrontal cortex, $p=0.013$ and temporal cortex, $p=0.015$ ), but these did not survive multiple comparison correction by the false discovery rate criterion.

\section{$\mathrm{D}_{1}$ Receptor Availability}

Representative PET scans are shown in Figure 1. There was no significant difference between groups for $\mathrm{BP}_{\mathrm{p}}$ and $\mathrm{BP}$ (multivariate analysis of variance, $p=0.35$ for $\mathrm{BP}_{\mathrm{p}}$ and $p=0.219$ for $\left.\mathrm{BP}_{\mathrm{ND}}\right)$. The values are provided in Table 2 . Unpaired $t$-tests on individual regions did not reach significance after correction for multiple comparisons according to the false discovery rate criterion. Although a decrease in $\mathrm{BP}_{\mathrm{P}}$ and $\mathrm{BP}_{\mathrm{ND}}$ was seen in the VST in the $\mathrm{CD}$ subjects compared with HCs, this difference did not reach significance.

\section{Cocaine Self-Administration Session Results}

In the sample sessions, the positive effects of cocaine varied with the dose. The area under the curve of the positive effects cluster of the $12 \mathrm{mg}$ dose $(314 \pm 622)$ was higher than that of the $0 \mathrm{mg}(135 \pm 441)$ and $6 \mathrm{mg}$ doses $(151 \pm 419)$ ( $p<0.05$ for both comparisons). No significant difference was seen between the positive effects of the 0 and $6 \mathrm{mg}$ doses $(p=0.30)$. As only the $12 \mathrm{mg}$ dose elicited positive subjective effects different from placebo, the effects of the $12 \mathrm{mg}$ dose were selected for comparison with the PET scan data.

In the choice sessions, subjects could choose cocaine 0-5 times. The $0 \mathrm{mg}$ dose was chosen on an average of $0.33 \pm 1.05$ times, the $6 \mathrm{mg}$ dose was chosen $1.58 \pm 1.67$ times, and the $12 \mathrm{mg}$ dose was chosen $3.21 \pm 1.61$ times. The $12 \mathrm{mg}$ dose was chosen more frequently than both the 0 and $6 \mathrm{mg}$ dose ( $p<0.001$ for both cases), and the $6 \mathrm{mg}$ dose was also chosen more frequently than the $0 \mathrm{mg}$ dose $(p=0.002)$. The rationale for using low doses of cocaine in the selfadministration sessions was to ensure enough variability between subjects to allow comparison with the PET data. The coefficient of variation was higher for the $6 \mathrm{mg}$ dose (1.05) compared with the $12 \mathrm{mg}$ (0.50). Therefore, the $6 \mathrm{mg}$ was chosen a priori for comparison with the PET data.

\section{Relationship Between Pet Data and Cocaine Self-Administration}

As shown in Figure 2, there was a significant negative correlation between $D_{1}$ receptor $B P_{N D}$ in the VST and the choice for cocaine $(r=-0.47, p=0.02$, corrected for age), such that the $C D$ subjects with the lowest values for $\mathrm{BP}_{\mathrm{ND}}$ were more likely to choose a $6 \mathrm{mg}$ dose of smoked cocaine. Exploratory analysis with the other striatal ROIs failed to show significant association between choice and $\mathrm{BP}_{\mathrm{ND}}$ (preDCA: $r=0.27, p=0.21$; preDPU: $r=0.19, p=0.37$; postCA: $r=0.12, p=0.60$; postPU: $r=0.05, p=0.83$; STR: $r=0.23, p=0.30)$. No correlation was seen between $\mathrm{BP}_{\mathrm{P}}$ in the VST, or any other ROI, and the choice to self-administer $6 \mathrm{mg}$ cocaine. No correlation was seen between $\mathrm{BP}_{\mathrm{P}}$ or $\mathrm{BP}_{\mathrm{ND}}$ in any brain region and the choice to self-administer the $12 \mathrm{mg}$ dose of cocaine. No correlation was seen between $\mathrm{BP}_{\mathrm{P}}$ or $\mathrm{BP}_{\mathrm{ND}}$ and the positive effects of the $12 \mathrm{mg}$ dose of cocaine.

A significant negative correlation was also seen between $\mathrm{BP}_{\mathrm{ND}}$ in the VST and years of cocaine use $(r=-0.59$,
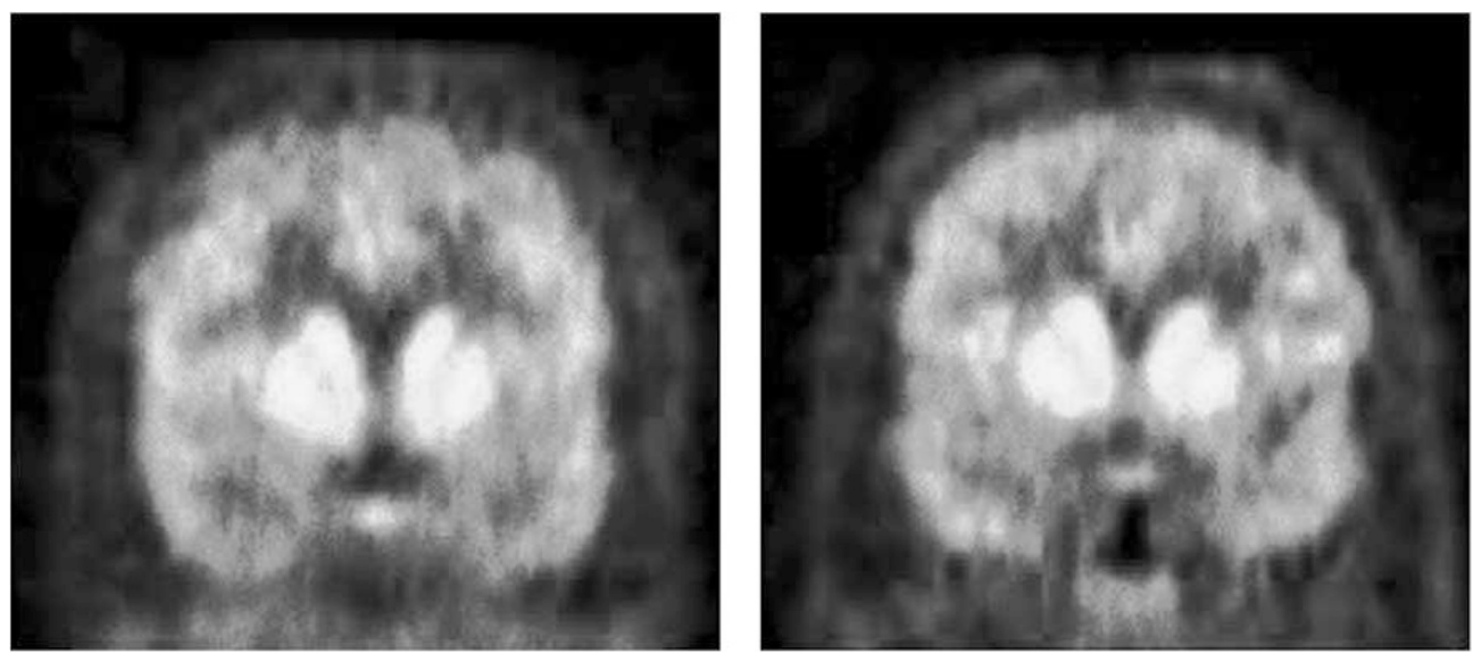

Figure I $\left[{ }^{\prime \prime} \mathrm{C}\right] \mathrm{NNC}$ I 12 distribution in a healthy control subject (left) and a cocaine-dependent subject (right). Both images are the mean of data acquired from 0-90 min and the image display was corrected for injected dose. The selected images include the striatum rostral to the anterior commissure. No significant difference in $D_{1}$ receptor availability was seen between the two groups. 
Table 2 [ ' $\mathrm{C}] \mathrm{NNC}$ I 12 binding potential $\left(\mathrm{BP}_{\mathrm{P}}, \mathrm{ml} / \mathrm{g}\right)$ and specific to non-specific partition coefficient (BP $\mathrm{ND}_{\mathrm{N}}$, unitless)

\begin{tabular}{|c|c|c|c|c|}
\hline \multirow[b]{2}{*}{ Region of interest } & \multicolumn{2}{|c|}{$\mathbf{B P}_{\mathbf{P}}$} & \multicolumn{2}{|c|}{$\mathbf{B P}_{\mathbf{N D}}$} \\
\hline & HC & CD & HC & CD \\
\hline \multicolumn{5}{|l|}{ Striatum } \\
\hline Ventral striatum & $5.03 \pm 1.61$ & $4.89 \pm 1.11$ & $2.32 \pm 0.51$ & $2.13 \pm 0.43$ \\
\hline Pre-commissural dorsal caudate & $6.02 \pm 1.57$ & $6.19 \pm 1.32$ & $2.78 \pm 0.43$ & $2.67 \pm 0.33$ \\
\hline Post-commissural dorsal putamen & $6.15 \pm 1.81$ & $6.45 \pm 1.26$ & $2.82 \pm 0.46$ & $2.80 \pm 0.32$ \\
\hline \multicolumn{5}{|l|}{ Subcortical } \\
\hline Amygdala & $1.08 \pm 026$ & $1.18 \pm 0.34$ & $0.51 \pm 0.11$ & $0.51 \pm 0.12$ \\
\hline Hippocampus & $0.66 \pm 0.26$ & $0.63 \pm 0.20$ & $0.31 \pm 0.11$ & $0.27 \pm 0.07$ \\
\hline Medial prefrontal cortex & $1.41 \pm 0.40$ & $1.35 \pm 0.27$ & $0.65 \pm 0.13$ & $0.59 \pm 0.08$ \\
\hline Orbitofrontal cortex & $1.00 \pm 0.35$ & $0.97 \pm 0.37$ & $0.47 \pm 0.15$ & $0.42 \pm 0.13$ \\
\hline Anterior cingulate & $1.54 \pm 0.43$ & $1.57 \pm 0.38$ & $0.71 \pm 0.13$ & $0.68 \pm 0.12$ \\
\hline Temporal cortex & $1.25 \pm 0.33$ & $1.27 \pm 0.30$ & $0.58 \pm 0.10$ & $0.55 \pm 0.09$ \\
\hline Parietal cortex & $1.24 \pm 0.38$ & $1.14 \pm 0.29$ & $0.57 \pm 0.13$ & $0.49 \pm 0.08$ \\
\hline Occipital cortex & $1.24 \pm 0.39$ & $1.22 \pm 0.28$ & $0.58 \pm 0.13$ & $0.53 \pm 0.08$ \\
\hline
\end{tabular}

CD, cocaine dependent; $\mathrm{HC}$, healthy control.

Values are Mean $\pm S D$. No significant differences were seen between the two groups.

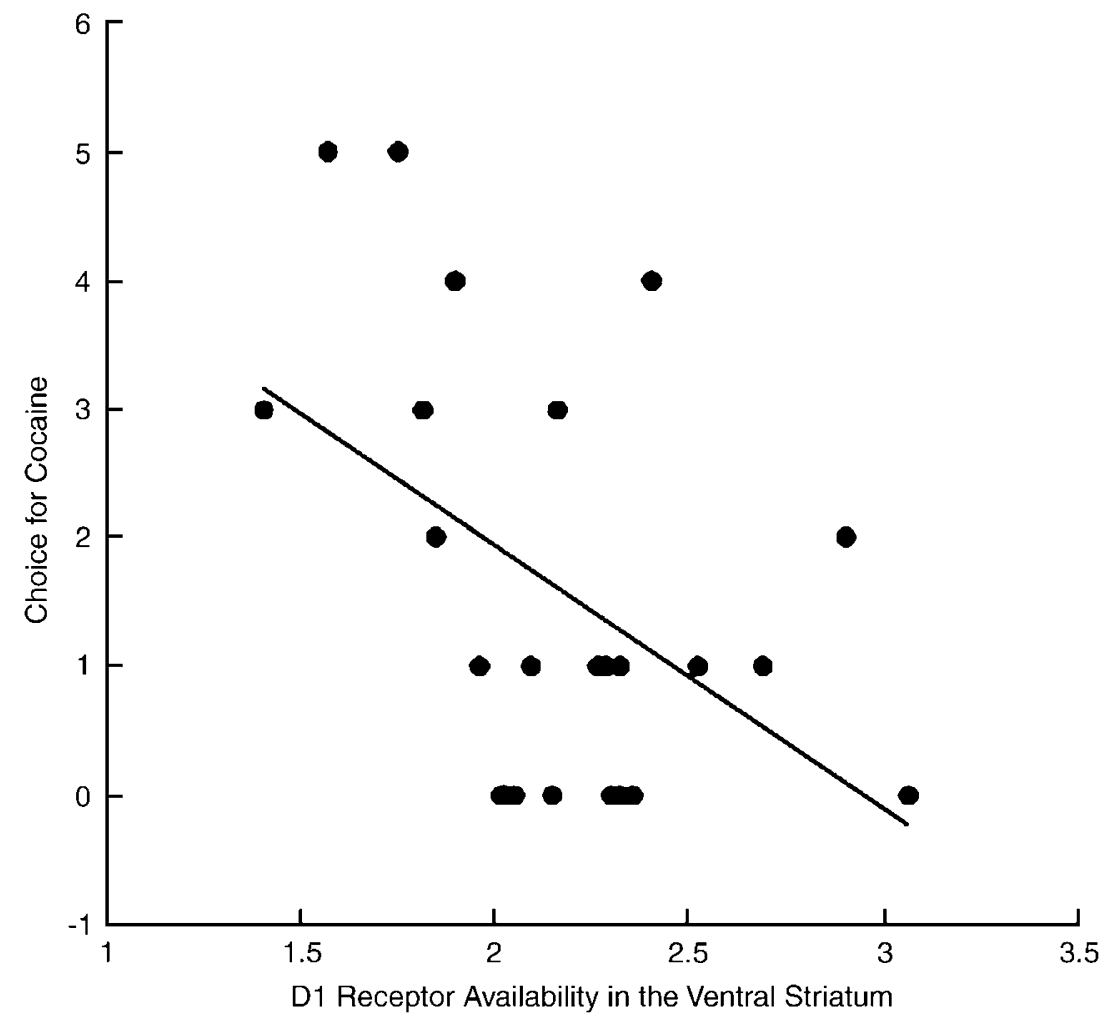

Figure 2 Correlation between [ ' $\mathrm{C}] \mathrm{NNC} / 12 \mathrm{BP}$ ND in the VST ( $x$ axis) and the choice to self-administer $6 \mathrm{mg}$ doses of cocaine ( $y$ axis, range $0-5$ ). A significant correlation was found between $D_{1}$ receptor availability and the choice to self-administer cocaine over an alternative reinforcer (voucher worth $\$ 5)(r=-0.47, p=0.02$, corrected for age). 
$p=0.01$, corrected for age). Exploratory analysis failed to detect significant correlation between years of use and $\mathrm{BP} \mathrm{PD}_{\mathrm{ND}}$ or $\mathrm{BP}_{\mathrm{P}}$ in any other striatal region.

\section{DISCUSSION}

The results of this study do not support the hypothesis that $\mathrm{D}_{1}$ receptor availability, measured with PET and the radiotracer $\left[{ }^{11} \mathrm{C}\right] \mathrm{NNC} 112$, is reduced in the VST of CD subjects compared with HCs. However, within the CD subjects, low $\mathrm{D}_{1}$ receptor availability in the VST may be associated with the choice to self-administer cocaine. In this study, an association was seen between $\left[{ }^{11} \mathrm{C}\right] \mathrm{NNC} 112 \mathrm{BP} \mathrm{ND}_{\mathrm{ND}}$ (although not $\mathrm{BP}_{\mathrm{P}}$ ) in the VST and the choice to selfadminister the $6 \mathrm{mg}$ dose of smoked cocaine.

\section{$\mathrm{D}_{1}$ Receptor Availability and Cocaine Dependence}

In this dataset, we found no significant difference in $\left[{ }^{11} \mathrm{C}\right] \mathrm{NNC} 112 \mathrm{BP}_{\mathrm{P}}$ or $\mathrm{BP}_{\mathrm{ND}}$ in each of the investigated ROIs. Although this finding is in agreement with a human post-mortem study reporting that striatal $D_{1}$ receptor mRNA is unchanged after chronic cocaine exposure (Meador-Woodruff et al, 1993), pre-clinical studies investigating this effect have not been consistent. Earlier studies in rodents have reported both an increase and a decrease in striatal $\mathrm{D}_{1}$ receptors after cocaine exposure (Kleven et al, 1990; Lim et al, 1990; Unterwald et al, 1994). To our knowledge, only one earlier study has used PET imaging and the radiotracer $\left[{ }^{11} \mathrm{C}\right] \mathrm{SCH} 23390$ to measure changes $\mathrm{D}_{1}$ receptor binding, and this study showed a significant decrease in $\mathrm{BP}_{\mathrm{ND}}$ in rodents after at least 7 days of cocaine administration (Tsukada et al, 1996).

Studies in non-human primates have also shown conflicting results. Two studies in rhesus monkeys have reported a decrease in $D_{1}$ receptor binding after cocaine exposure. Farfel et al reported that 14 days of experimenteradministered cocaine followed by 14 days withdrawal resulted in a decrease in $D_{1}$ receptor density in the caudate, with no change in the nucleus accumbens (Farfel et al, 1992). A subsequent study used $\left[{ }^{3} \mathrm{H}\right] \mathrm{SCH} 23390$ to label the $D_{1}$ receptor, and reported decreased binding in the nucleus accumbens in rhesus monkeys who self-administered cocaine for 18-22 months (Moore et al, 1998). However, two other studies in rhesus monkeys have used $\left[{ }^{3} \mathrm{H}\right] \mathrm{SCH} 23390$ to label the $\mathrm{D}_{1}$ receptor and shown increases in receptor binding after cocaine self-administration. The study by Nader et al (Nader et al, 2002) showed that 100 days of cocaine self-administration increased $D_{1}$ receptor binding in the dorsolateral and ventromedial caudate and putamen in addition to the shell of the nucleus accumbens. More recently, Beveridge et al (Beveridge et al, 2008) used the same paradigm and showed similar results, but also showed that $D_{1}$ receptor binding returned to baseline after 90 days of abstinence. Overall, these data in animals suggest that $D_{1}$ receptor availability may vary with respect to the duration of cocaine exposure and abstinence, and a recent study in rodents also showed that $D_{1}$ receptor binding varies with the time of withdrawal (Ben-Shahar et al, 2007). In this study, the CD participants had a long history of cocaine exposure, such that the design of this study is more in line with that of Moore et al (Moore et al, 1998). Although we saw a decrease in striatal $D_{1}$ receptor availability, it was not significant. However, it is possible that $D_{1}$ receptor $B P$ might have been lower had we performed the PET scans after a shorter duration of abstinence. In other words, it is possible that the cocaine subjects had lower $\mathrm{D}_{1}$ receptor $\mathrm{BP}$ prior to the 14 days of abstinence, and in this study, they were scanned as $D_{1}$ receptor density was returning to baseline.

Another potential issue that must be considered in this study is that of cigarette smoking. An earlier PET study using the radiotracer $\left[{ }^{11} \mathrm{C}\right] \mathrm{NNC} 112$ reported a decrease in $D_{1}$ receptor availability in the VST of cigarette smokers compared with non-smokers (Dagher et al, 2001). In this study, subjects were matched for smoking, so it is unlikely that smoking status was a source of artifact. Nevertheless, we performed a two-way ANOVA with group (HC and CD) and smoking status (non-smokers and ex-smokers pooled) as treatments. In fact VST $\mathrm{BP}_{\mathrm{ND}}$ was higher among smokers than non-smokers at trend level (smokers $=2.30 \pm 0.46$, non-smokers $=2.04 \pm 0.46, p=0.078$ ), though the group by smoker interaction was not significant $(p=0.613)$.

It is also possible that this study lacked the power to detect a between group difference. If the variance observed in this study is taken as an estimate of population variance, then the between group difference in $\mathrm{BP}_{\mathrm{ND}}$ required to reach significance would be about $17 \%$ (for $\alpha=0.05$ critical level and $1-\beta=0.8$ power). However, we saw only a nonsignificant decrease of $8 \%$ in $\mathrm{BP}_{\mathrm{ND}}$ in the VST, and less of a difference in the other striatal regions.

\section{$\mathrm{D}_{1}$ Receptor Transmission and Cocaine Dependence}

Earlier pre-clinical studies have shown conflicting results with respect to the effects of $\mathrm{D}_{1}$ agonist and antagonist administration on the behavioral effects of cocaine administration. Earlier studies have shown that $D_{1}$ agonists reduce cocaine-seeking behavior (De Vries et al, 1999; Milivojevic et al, 2004; Self et al, 1996b), decrease cocaine selfadministration (Barrett et al, 2004; Caine et al, 1999), and increased the latency for cue-induced cocaine-seeking behavior (Alleweireldt et al, 2002). In addition, a recent study in $D_{1}$ knockout mice showed that the $D_{1}$ receptor is crucial for mediating the reinforcing effects of cocaine (Caine et al, 2007). Similar results have been reported in non-human primates (Katz and Witkin, 1992; Khroyan et al, 2000; Mutschler and Bergman, 2002; Platt et al, 2001). However, the opposite effect has also been shown, in which $\mathrm{D}_{1}$ antagonist administration attenuates priming- and cueinduced cocaine-seeking behavior (Alleweireldt et al, 2002; Barrett et al, 2004; Khroyan et al, 2000, 2003; Kleven and Woolverton, 1990), blocks cocaine-induced conditioned place preference (Baker et al, 1998; Nazarian et al, 2004), and blocks the reinstatement of cocaine self-administration (Bachtell et al, 2005; Schmidt and Pierce, 2006). In short, some studies show that $D_{1}$ receptor activation may inhibit cocaine-seeking behavior, whereas other studies suggest that $D_{1}$ receptor blockade may have a more beneficial effect.

Studies in humans, although limited, suggest that stimulation of $D_{1}$ receptors in humans may reduce the reinforcing effects of cocaine, whereas blockade of the $D_{1}$ receptor enhances the reinforcing effects. In a study of $C D$ 
participants, the $\mathrm{D}_{1}$ antagonist SCH 39166 has been shown to increase both cocaine self-administration in addition to the subjective measures of 'High,' 'Stimulated,' and 'Good Drug Effect' (Haney et al, 2001). Alternatively, the administration of ABT-431, a full agonist at the $\mathrm{D}_{1}$ receptor, to CD subjects significantly decreased the positive subjective effects of cocaine (Haney et al, 1999). ABT-431 did not significantly affect cocaine self-administration, although its dosage is limited in humans because of its side effects.

\section{$D_{1}$ Receptor Availability and the Addictive Phenotype}

In this study, low $\mathrm{D}_{1}$ receptor availability correlated with both the choice to self-administer low-dose cocaine and years of cocaine use. This finding suggests that low $D_{1}$ receptor binding potential may be indicative of a particular phenotype. $C D$ subjects with low $D_{1}$ receptor binding may have a more severe addiction, such that they are more vulnerable to the effects of a priming dose of cocaine and self-administer more cocaine. This is in agreement with the recent study investigating the 'addictive phenotype' in rodents (Edwards et al, 2007). In this study, rodents trained to self-administer cocaine were characterized as having higher $v s$ lower preferred levels of cocaine intake. The rodents with higher levels of cocaine intake were found to be less sensitive to the effects of $D_{1}$ receptor agonist in reducing cocaine-induced reinstatement of cocaine-seeking behavior (Edwards et al, 2007). Notably, chronic cocaine exposure produces a persistent upregulation of cAMP-PKA pathways in the nucleus accumbens, which then weakens further $D_{1}$ receptor signaling and down-regulates $D_{1}$ receptor expression (Self, 2004; Ventura and Sibley, 2000). Thus, we had hypothesized that cocaine dependence would be associated with a decrease in $D_{1}$ receptor binding compared with HCs. Although we did see a decrease in $\left[{ }^{11} \mathrm{C}\right] \mathrm{NNC} 112 \mathrm{BP}_{\mathrm{ND}}$ in the LST, it was not significant $\left(\mathrm{BP}_{\mathrm{ND}}\right.$ was 2.32 in $\mathrm{HC} v s 2.13$ in $\mathrm{CD}, p=0.17$, two group $t$-test, not corrected for multiple observations). However, the possibility remains that $\mathrm{CD}$ subjects who chose to self-administer higher doses of cocaine may represent a phenotype in which $D_{1}$ receptor binding is decreased in the LST. In order to test this hypothesis, we performed a post hoc analysis, in which the CD subjects were divided into two groups: those who self-administered 0 or 1 dose of cocaine and those who selfadministered 2-5 doses of cocaine. This analysis showed that the low (0-1) self-administration group had a higher $\mathrm{D}_{1}$ receptor $\mathrm{BP}_{\mathrm{ND}}$ compared with those who self-administered $2-5$ doses of cocaine $\left(\mathrm{BP}_{\mathrm{ND}}\right.$ was 2.32 in low self-administration group $v s 2.13$ in the high self-administration group, $p=0.04)$. This finding is consistent with the hypothesis that a phenotype of $C D$ subjects with low $D_{1}$ receptor binding in the VST may represent a group with greater vulnerability to the reinforcing effects of cocaine.

\section{Study Limitations}

The limitations of this study include the lack of a significant correlation between $\mathrm{BP}_{\mathrm{P}}$ and the choice to self-administer cocaine, the lack of a correlation between the choice to administer the $12 \mathrm{mg}$ dose of cocaine and $\mathrm{BP}_{\mathrm{ND}}$, and the lack of selectivity of $\left[{ }^{11} \mathrm{C}\right] \mathrm{NNC} 112$ for $\mathrm{D}_{1}$ vs serotonin type 2A receptor (5-HT2A) receptors (Slifstein et al, 2007).
Although there was evidence of a negative correlation between $\left[{ }^{11} \mathrm{C}\right] \mathrm{NNC} 112 \mathrm{BP}_{\mathrm{P}}$ and the choice to selfadminister the $6 \mathrm{mg}$ dose of cocaine, this was not significant $(r=-0.30, p=0.19)$. Thus, it is possible that this study lacked the power to detect a correlation with $\mathrm{BP}_{\mathrm{P}}$, given that this outcome measure has a higher variability than $\mathrm{BP}_{\mathrm{ND}}$. The lack of a correlation between the $12 \mathrm{mg}$ dose of cocaine and $\left[{ }^{11} \mathrm{C}\right] \mathrm{NNC} 112$ binding (both $\mathrm{BP}_{\mathrm{P}}$ and $\mathrm{BP}_{\mathrm{ND}}$ ) may be because of the lower coefficient of variation seen with the $12 \mathrm{mg}$ self-administration sessions. The majority of subjects (17 of 24) self-administered 3 or more doses of the $12 \mathrm{mg}$ dose in the cocaine self-administration sessions, so that there may have been insufficient variability to detect a correlation. Lastly, although $\sim 30 \%$ of the binding of $\left[{ }^{11} \mathrm{C}\right] \mathrm{NNC} 112$ can be attributed to the 5-HT2A receptor in the cortex, there does not appear to be any significant binding to the 5-HT2A receptor in the STR (Slifstein et al, 2007). The same is also true for $\left[{ }^{11} \mathrm{C}\right] \mathrm{SCH} 23390$, so that the difference seen between this study and that of Tsukada et al (Tsukada et al, 1996) cannot be attributed to this issue.

\section{ACKNOWLEDGEMENTS}

The authors would like to thank Mabel Torres, Erica Scher, Ingrid Gelbard-Stokes, Elizabeth Hackett, and Hemant Belani for their excellent technical assistance. This study was supported by the Public Health Service NIDA PA50 DA 09236, NIDA K23 DA00483, and NIH M01RR00645.

\section{DISCLOSURE/CONFLICT OF INTEREST}

The authors report no conflicts of interest associated with the content of this paper.

Diana Martinez: no disclosures.

Mark Slifstein: received compensation for professional services from Glaxo-Smith-Kline, Amgen, and Yale University.

Rajesh Narendran: no disclosures.

Richard W Foltin: no disclosures.

Allegra Broft : no disclosures.

Dah-Ren Hwang: currently an employee of Amgen.

Audrey Perez: no disclosures.

Anissa Abi-Dargham: received compensation for professional services from Bristol Meyers Squibb-Otsuka, SanofiAventis, Vanda Pharmaceuticals, Eli Lilly and Company. Herbert D Kleber: no disclosures.

Marc Laruelle: currently an employee of Glaxo-Smith-Kline.

\section{REFERENCES}

Abi-Dargham A, Martinez D, Mawlawi O, Simpson N, Hwang DR, Slifstein $\mathrm{M}$ et al (2000). Measurement of striatal and extrastriatal dopamine $\mathrm{D}_{1}$ receptor binding potential with $\left[{ }^{11} \mathrm{C}\right] \mathrm{NNC} 112$ in humans: validation and reproducibility. J Cereb Blood Flow Metab 20: 225-243.

Alleweireldt AT, Weber SM, Kirschner KF, Bullock BL, Neisewander JL (2002). Blockade or stimulation of $\mathrm{D}_{1}$ dopamine receptors attenuates cue reinstatement of extinguished cocaine-seeking behavior in rats. Psychopharmacology (Berl) 159: 284-293.

Bachtell RK, Whisler K, Karanian D, Self DW (2005). Effects of intra-nucleus accumbens shell administration of dopamine agonists and antagonists on cocaine-taking and cocaine- 
seeking behaviors in the rat. Psychopharmacology (Berl) 183: 4153.

Baker DA, Fuchs RA, Specio SE, Khroyan TV, Neisewander JL (1998). Effects of intraaccumbens administration of SCH-23390 on cocaine-induced locomotion and conditioned place preference. Synapse 30: 181-193.

Barrett AC, Miller JR, Dohrmann JM, Caine SB (2004). Effects of dopamine indirect agonists and selective $\mathrm{D}_{1}$-like and D2-like agonists and antagonists on cocaine self-administration and food maintained responding in rats. Neuropharmacology 47(Suppl 1): 256-273.

Ben-Shahar O, Keeley P, Cook M, Brake W, Joyce M, Nyffeler M et al (2007). Changes in levels of D1, D2, or NMDA receptors during withdrawal from brief or extended daily access to IV cocaine. Brain Res 1131: 220-228.

Beveridge TJ, Smith HR, Nader MA, Porrino LJ (2008). Abstinence from chronic cocaine self-administration alters striatal dopamine systems in rhesus monkeys. Neuropsychopharmacology. [e-pub ahead of print].

Caine SB, Heinrichs SC, Coffin VL, Koob GF (1995). Effects of the dopamine D-1 antagonist SCH 23390 microinjected into the accumbens, amygdala or striatum on cocaine self-administration in the rat. Brain Res 692: 47-56.

Caine SB, Negus SS, Mello NK, Bergman J (1999). Effects of dopamine $\mathrm{D}$ (1-like) and $\mathrm{D}$ (2-like) agonists in rats that selfadminister cocaine. J Pharmacol Exp Ther 291: 353-360.

Caine SB, Thomsen M, Gabriel KI, Berkowitz JS, Gold LH, Koob GF et al (2007). Lack of self-administration of cocaine in dopamine $\mathrm{D}_{1}$ receptor knock-out mice. J Neurosci 27: 13140-13150.

Dagher A, Bleicher C, Aston JA, Gunn RN, Clarke PB, Cumming P (2001). Reduced dopamine $D_{1}$ receptor binding in the ventral striatum of cigarette smokers. Synapse 42: 48-53.

De Vries TJ, Schoffelmeer AN, Binnekade R, Vanderschuren LJ (1999). Dopaminergic mechanisms mediating the incentive to seek cocaine and heroin following long-term withdrawal of IV drug selfadministration. Psychopharmacology (Berl) 143: 254-260.

Dias C, Lachize S, Boilet V, Huitelec E, Cador M (2004). Differential effects of dopaminergic agents on locomotor sensitisation and on the reinstatement of cocaine-seeking and food-seeking behaviour. Psychopharmacology (Berl) 175: 414-427.

Edwards S, Whisler KN, Fuller DC, Orsulak PJ, Self DW (2007). Addiction-related alterations in D1 and D2 dopamine receptor behavioral responses following chronic cocaine self-administration. Neuropsychopharmacology 32: 354-366.

Evans SM, Haney M, Foltin RW (2002). The effects of smoked cocaine during the follicular and luteal phases of the menstrual cycle in women. Psychopharmacology (Berl) 159: 397-406.

Farfel GM, Kleven MS, Woolverton WL, Seiden LS, Perry BD (1992). Effects of repeated injections of cocaine on catecholamine receptor binding sites, dopamine transporter binding sites and behavior in rhesus monkey. Brain Res 578: 235-243.

Foltin RW, Fischman MW, Nestadt G, Stromberger H, Cornell EE, Pearlson GD (1990). Demonstration of naturalistic methods for cocaine smoking by human volunteers. Drug Alcohol Depend 26: 145-154.

Foltin RW, Ward AS, Collins ED, Haney M, Hart CL, Fischman MW (2003). The effects of venlafaxine on the subjective, reinforcing, and cardiovascular effects of cocaine in opioiddependent and non-opioid-dependent humans. Exp Clin Psychopharmacol 11: 123-130.

Haber SN, Fudge JL (1997). The primate substantia nigra and VTA: Integrative circuitry and function. Crit Rev Neurobiol 11: 323-342.

Halldin C, Foged C, Chou YH, Karlsson P, Swahn CG, Sandell J et al (1998). Carbon-11-NNC 112: a radioligand for PET examination of striatal and neocortical D1-dopamine receptors. J Nucl Med 39: 2061-2068.
Haney M, Collins ED, Ward AS, Foltin RW, Fischman MW (1999). Effect of a selective dopamine D1 agonist (ABT-431) on smoked cocaine self-administration in humans. Psychopharmacology (Berl) 143: 102-110.

Haney M, Ward AS, Foltin RW, Fischman MW (2001). Effects of ecopipam, a selective dopamine D1 antagonist, on smoked cocaine self-administration by humans. Psychopharmacology (Berl) 155: 330-337.

Innis RB, Cunningham VJ, Delforge J, Fujita M, Gjedde A, Gunn $\mathrm{RN}$ et al (2007). Consensus nomenclature for in vivo imaging of reversibly binding radioligands. J Cereb Blood Flow Metab 27: 1533-1539.

Joel D, Weiner I (2000). The connections of the dopaminergic system with the striatum in rats and primates: an analysis with respect to the functional and compartmental organization of the striatum. Neuroscience 96: 451-474.

Katz JL, Witkin JM (1992). Selective effects of the D1 dopamine receptor agonist, SKF 38393, on behavior maintained by cocaine injection in squirrel monkeys. Psychopharmacology 109: 241-244.

Khroyan TV, Barrett-Larimore RL, Rowlett JK, Spealman RD (2000). Dopamine D1- and D2-like receptor mechanisms in relapse to cocaine-seeking behavior: effects of selective antagonists and agonists. J Pharmacol Exp Ther 294: 680-687.

Khroyan TV, Platt DM, Rowlett JK, Spealman RD (2003). Attenuation of relapse to cocaine seeking by dopamine D1 receptor agonists and antagonists in non-human primates. Psychopharmacology (Berl) 168: 124-131.

Kleven MS, Perry BD, Woolverton WL, Seiden LS (1990). Effects of repeated injections of cocaine on D1 and D2 dopamine receptors in rat brain. Brain Res 532: 265-270.

Kleven MS, Woolverton WL (1990). Effects of continuous infusions of SCH 23390 on cocaine- or food-maintained behavior in rhesus monkeys. Behav Pharmacol 1: 365-373.

Lim DK, Yu ZJ, Hoskins B, Rockhold RW, Ho IK (1990). Effects of acute and subacute cocaine administration on the CNS dopaminergic system in Wistar-Kyoto and spontaneously hypertensive rats: II Dopamine receptors. Neurochem Res 15: 621-627.

Maldonado R, Robledo P, Chover AJ, Caine SB, Koob GF (1993). D1 dopamine receptors in the nucleus accumbens modulate cocaine self-administration in the rat. Pharmacol Biochem Behav 45: 239-242.

Martinez D, Broft A, Foltin RW, Slifstein M, Hwang DR, Huang Y et al (2004). Cocaine dependence and $\mathrm{d} 2$ receptor availability in the functional subdivisions of the striatum: relationship with cocaine-seeking behavior. Neuropsychopharmacology 29: $1190-1202$

Martinez D, Slifstein M, Broft A, Mawlawi O, Hwang DR, Huang Y et al (2003). Imaging human mesolimbic dopamine transmission with positron emission tomography. Part II: amphetamineinduced dopamine release in the functional subdivisions of the striatum. J Cereb Blood Flow Metab 23: 285-300.

Meador-Woodruff JH, Little KY, Damask SP, Mansour A, Watson SJ (1993). Effects of cocaine on dopamine receptor gene expression: a study in the postmortem human brain. Biol Psychiatry 34: 348-355.

Milivojevic N, Krisch I, Sket D, Zivin M (2004). The dopamine D1 receptor agonist and D2 receptor antagonist LEK-8829 attenuates reinstatement of cocaine-seeking in rats. Naunyn Schmiedebergs Arch Pharmacol 369: 576-582.

Mintun MA, Raichle ME, Kilbourn MR, Wooten GF, Welch MJ (1984). A quantitative model for the in vivo assessment of drug binding sites with positron emission tomography. Ann Neurol 15: 217-227.

Moore RJ, Vinsant SL, Nader MA, Porrino LJ, Friedman DP (1998). Effect of cocaine self-administration on striatal dopamine D1 receptors in rhesus monkeys. Synapse 28: 1-9.

Mutschler NH, Bergman J (2002). Effects of chronic administration of the D1 receptor partial agonist SKF 77434 on cocaine self- 
administration in rhesus monkeys. Psychopharmacology (Berl) 160: 362-370.

Nader MA, Daunais JB, Moore T, Nader SH, Moore RJ, Smith HR et al (2002). Effects of Cocaine Self-administration on Striatal Dopamine Systems in Rhesus Monkeys. Initial and Chronic Exposure. Neuropsychopharmacology 27: 35-46.

Nazarian A, Russo SJ, Festa ED, Kraish M, Quinones-Jenab V (2004). The role of D1 and D2 receptors in the cocaine conditioned place preference of male and female rats. Brain Res Bull 63: 295-299.

Platt DM, Rowlett JK, Spealman RD (2001). Modulation of cocaine and food self-administration by low- and high-efficacy D1 agonists in squirrel monkeys. Psychopharmacology (Berl) 157: 208-216.

Schmidt HD, Pierce RC (2006). Cooperative activation of D1-like and D2-like dopamine receptors in the nucleus accumbens shell is required for the reinstatement of cocaine-seeking behavior in the rat. Neuroscience 142: 451-461.

Self D (2004). Drug dependence and addiction: neural substrates. Am J Psychiatry 161: 223.

Self DW, Barnhart WJ, Lehman DA, Nestler EJ (1996a). Opposite modulation of cocaine-seeking behavior by D1- and D2-like dopamine receptor agonists. Science 271: 1586-1589.

Self DW, Belluzzi JD, Kossuth S, Stein L (1996b). Self-administration of the D1 agonist SKF 82958 is mediated by D1, not D2, receptors. Psychopharmacology (Berl) 123: 303-306.

Self DW, Karanian DA, Spencer JJ (2000). Effects of the novel D1 dopamine receptor agonist ABT-431 on cocaine self-administration and reinstatement. Ann N Y Acad Sci 909: 133-144.
Shaham Y, Shalev U, Lu L, De Wit H, Stewart J (2003). The reinstatement model of drug relapse: history, methodology and major findings. Psychopharmacology (Berl) 168: 3-20.

Slifstein M, Kegeles LS, Gonzales R, Frankle WG, Xu X, Laruelle M et al (2007). $\left[{ }^{11} \mathrm{C}\right] \mathrm{NNC} 112$ selectivity for dopamine $\mathrm{D} 1$ and serotonin 5-HT(2A) receptors: a PET study in healthy human subjects. J Cereb Blood Flow Metab 27: 1733-1741.

Slifstein M, Laruelle M (2001). Models and methods for derivation of in vivo neuroreceptor parameters with PET and SPECT reversible radiotracers. Nucl Med Biol 28: 595-608.

Tsukada H, Kreuter J, Maggos CE, Unterwald EM, Kakiuchi T, Nishiyama S et al (1996). Effects of binge pattern cocaine administration on dopamine D1 and D2 receptors in the rat brain: an in vivo study using positron emission tomography. J Neurosci 16: 7670-7677.

Unterwald EM, Ho A, Rubenfeld JM, Kreek MJ (1994). Time course of the development of behavioral sensitization and dopamine receptor up-regulation during binge cocaine administration. J Pharmacol Exp Ther 270: 1387-1396.

Ventura AL, Sibley DR (2000). Altered regulation of the $\mathrm{D}(1)$ dopamine receptor in mutant Chinese hamster ovary cells deficient in cyclic AMP-dependent protein kinase activity. J Pharmacol Exp Ther 293: 426-434.

Woods RP, Cherry SR, Mazziotta JC (1992). Rapid automated algorithm for aligning and reslicing PET images. J Comput Assist Tomogr 16: 620-633.

Woods RP, Mazziotta JC, Cherry SR (1993). MRI-PET registration with automated algorithm. J Comput Assist Tomogr 17: 536-546. 